\title{
Editorial
}

\section{The Role of Pre-Assessment in Oesophageal Cancer Surgery}

\author{
Niven Akotia, MBBS, BSc, MSc, FRCA';Alexandros Charalabopoulos, MD, MSc, PhD, MRCS, FRCS ${ }^{2 *}$ \\ 'Department of Anaesthesia, Broomfield Hospital, Mid Essex Hospital Services NHS Trust, Chelmsford, Essex, UK \\ ${ }^{2}$ Department of Upper Gastrointestinal Surgery, Regional Oesophagogastric Unit, Broomfield Hospital, Mid Essex Hospital Services NHS Trust, Chelmsford, \\ Essex, England, UK
}

\section{${ }^{*}$ Corresponding author}

Alexandros Charalabopoulos, MD, MSc, PhD, MRCS, FRCS

Department of Upper Gastrointestinal Surgery, Regional Oesophagogastric Unit, Broomfield Hospital, Mid Essex Hospital Services NHS Trust, Chelmsford, Essex, England, UK; E-mail: acharalabopoulos@yahoo.com

\section{Article information}

Received: September II ${ }^{\text {th }}, 2017$; Accepted: September 18 ${ }^{\text {th }}, 2017$; Published: September 18 th $^{\text {th }} 2017$

\section{Cite this article}

Akotia N, Charalabopoulos A. The role of pre-assessment in oesophageal cancer surgery. Gastro Open J. 20I7; 3(I): el-e3. doi: I0.17।40/GOJ-3-e004

$\mathrm{N}$ ational figures for oesophagectomy mortality in the United Kingdom have been steadily dropping (12\% to $9 \%)$ since the late 1990's. ${ }^{1}$ More recently, these figures have improved significantly as shown in the 2016 annual report of the UK National Oesophago-Gastric Cancer Audit (NOGCA), revealing a post-oesophagectomy 90 -day mortality rate of $3.2 \% .{ }^{2}$ Despite this, surgical treatment for oesophageal cancer still carries significant morbidity, often quoted up to $64 \% .{ }^{3}$ While centres of excellence maintain high standards of surgery and improved surgical techniques, with minimally invasive techniques potentially reducing physiological stresses on patients, we are perhaps being less conservative in our selection of patients for surgery; all having varying influences on the overall risks.

Pre-assessment of patients over the last 2 decades has dramatically changed. We have moved from pre-assessment being performed by the most junior members of the surgical team in the past, to the current system with dedicated consultants and nurse specialists, specializing in peri-operative medicine. This has been shown to decrease cancellations of surgery, reduce length of stay in a number of surgical specialities and potentially improve the outcome. $^{4,5}$

The primary aim is to balance the impact of the stress of surgery and the overall physiological reserve of the patient, to provide some idea of the individual's risk of morbidity and mortality. Based on this initial assessment, any specific risks would be highlighted and strategies to mitigate these would be implemented, thus, attempting to tip the balance to lower those risks.

\section{RISK ASSESSMENT}

Currently, a number of scoring systems are used to evaluate the co- morbidities and physiological reserve in patients. All have limitations and relatively poor specificity but by combining scores, evaluation could be improved. The most commonly used scoring system worldwide is the American Society of Anaesthesiologists (ASA) Physical Status. Its limitations include lack of specificity and a large inter-assessor variability. ${ }^{6}$ Others are Lee's Revised Cardiac Index and POSSUM score. ${ }^{7}$ Another well-known system is the Charlson Comorbidity Index, which determines increased risk based on the number and severity of each of the co-morbidities the patient has. This has been validated both in gastric and oesophageal cancer as a predictor of mortality. ${ }^{8}$ Repeatedly, age has not been shown to be a predictor of morbidity and mortality; rather, the co-morbidities and the overall fitness of the patient need to be weighed to determine the overall risk. ${ }^{9}$

Frailty is therefore becoming one of the strongest predictors of outcome in oesophagectomy patients. Associated with frailty is sarcopenia, which is recognised as a global quantitative marker of frailty, and could potentially be used to assist with assessment. Here sarcopenia, which is age-related muscle mass and strength loss, should be differentiated from cachexia, which may be due to malignancy or its treatment with chemotherapy. ${ }^{10}$

Cardiopulmonary exercise testing (CPET) is increasingly being used to risk stratify patients undergoing complex gastrointestinal surgery. Anaerobic threshold (AT) has been extensively associated with cardiovascular risk stratification in many surgical subspecialties. In oesophageal cancer resections, an AT of less than $11 \mathrm{ml} / \mathrm{kg} / \mathrm{min}$ has been shown to be an indicator of increased cardiopulmonary complications as well as predicting a higher rate of unplanned intensive care unit admissions. ${ }^{11}$ More recently another marker that is considered to perhaps be an even more accurate predictor of cardiopulmonary complications is the 
maximum oxygen uptake $\left(\mathrm{VO}_{2}\right.$ max). In a Japanese study of $91 \mathrm{pa}-$ tients who had undergone radical oesophagectomy for cancer with 3-field lymph node dissection, $\mathrm{VO}_{2}$ max was found to correlate with cardiopulmonary complication rate, with a minimum cut-off at $800 \mathrm{ml} \cdot \mathrm{min}^{-1} \cdot \mathrm{m}^{-2}{ }^{12}$ Patients with $\mathrm{VO}_{2}$ max above that had a low cardiopulmonary complication rate and it was recommended that radical oesophagectomy was safe within that patient cohort. On the contrary, with a $\mathrm{VO}_{2}$ max between 700 to $799 \mathrm{ml} \cdot \mathrm{min}^{-1} \cdot \mathrm{m}^{-2}$, a cardiopulmonary complication rate of $44 \%$ was shown, whereas when the $\mathrm{VO}_{2}$ max was dropping below $699 \mathrm{ml} \cdot \mathrm{min}^{-1} \cdot \mathrm{m}^{-2}$, cardiopulmonary complication rate was in the area of $86 \%$. Certainly, further work in this area is sorely needed to exploit this useful mode of assessment.

\section{PRE-HABILITATION}

CPET has been used successfully in orthopaedics and more recently in colorectal cancer to improve post-operative recovery. ${ }^{13,14}$ Ongoing clinical trials are underway looking at the effect of prehabilitation in patients undergoing treatment for oesophageal cancer. ${ }^{15}$ The approach is of a trimodal one to improve a patients overall well-being through exercise, nutrition (protein supplementation), and psychological support (anxiety reduction). This is believed to have a greater impact on patients through improved compliance and marginal gains. ${ }^{13,16,17}$

\section{OPTIMISATION}

As the patient's journey prior to surgery often involves investigations and possible treatment with neo-adjuvant chemotherapy, there is an opportunity to improve the co-morbidities to further reduce peri-operative risks weeks before surgery. Smoking cessation, anaemia control, hypertension and diabetic management are but a few conditions that these patients often have as well. Optimising these prior to surgery could reduce their overall peri-operative risks.

\section{FUTURE}

Pre-assessment for oesophageal cancer is continuing to improve with models of care learnt from other areas of medicine and surgical sub-specialties. Enhanced recovery principles along with tailoring patient's pre-operative care through pre-habilitation could greatly improve oesophageal surgical outcome with development of adequate evidence-based support.

\section{CONFLICTS OF INTEREST}

The authors declare that they have no conflicts of interest.

\section{REFERENCES}

1. Al-Sarira AA, David G, Willmott S, Slavin JP, Deakin M, Corless DJ. Oesophagectomy practice and outcomes in England. BrJ Surg. 2007; 94(5): 585-591. doi: 10.1002/bjs.5805

2. AUGIS. 2016 National Oesophago-gastric Cancer Audit [In- ternet]. 2016. Web site. http://www.augis.org/national-oesophago-gastric-cancer-audit/. Accessed September 8, 2017.

3. Atkins BZ, Shah AS, Hutcheson KA, et al. Reducing hospital morbidity and mortality following esophagectomy. Ann Thor Surg. 2004; 78(4): 1170-1176. doi: 10.1016/j.athoracsur.2004.02.034

4. Cantlay KL, Baker S, Parry A, Danjoux G. The impact of a consultant anaesthetist led pre-operative assessment clinic on patients undergoing major vascular surgery. Anaesthesia. 2006; 61(3): 234239. doi: 10.1111/j.1365-2044.2005.04514.x

5. Hocking G, Shaikh L. Anaesthetic pre-assessment clinics to identify patients at risk. Anaesthesia. 2000; 55(8): 812-812. doi: 10.1046/j.1365-2044.2000.01629-3.x

6. Tegels JJ. Improving the outcomes in gastric cancer surgery. World J Gastroenterol. 2014; 20(38): 13692-13704. doi: 10.3748/wjg. v20.i38.13692

7. Bhagwat M, Paramesh K. Cardio-pulmonary exercise testing: An objective approach to pre-operative assessment to define level of perioperative care. Indian J Anaesth. 2010; 54(4): 286-291. doi: 10.4103/0019-5049.68369

8. Ra J, Paulson EC, Kucharczuk J, et al. Postoperative mortality after esophagectomy for cancer: Development of a preoperative risk prediction model. Ann Surg Oncol. 2008; 15(6): 1577-1584. doi: 10.1245/s10434-008-9867-4

9. Markar SR, Low DE. Physiology, not chronology, dictates outcomes after esophagectomy for esophageal cancer: Outcomes in patients 80 years and older. Ann Surg Oncol. 2013; 20(3): 1020-1026. doi: 10.1245/s10434-008-9867-4

10. Wagner D. Role of frailty and sarcopenia in predicting outcomes among patients undergoing gastrointestinal surgery. World J Gastrointest Surg. 2016; 8(1): 27-40. doi: 10.4240/wjgs.v8.i1.27

11. Moyes LH, McCaffer CJ, Carter RC, Fullarton GM, Mackay $\mathrm{CK}$, Forshaw MJ. Cardiopulmonary exercise testing as a predictor of complications in oesophagogastric cancer surgery. Ann R Coll Surg Engl. 2013; 95(2): 125-130. doi: 10.1308/rcsann.2013.95.2.125

12. Nagamatsu Y, Shima I, Yamana H, Fujita H, Shirouzu K, Ishitake T. Preoperative evaluation of cardiopulmonary reserve with the use of expired gas analysis during exercise testing in patients with squamous cell carcinoma of the thoracic esophagus. J Thorac Cardiovasc Surg. 2001;121(6): 1064-1068. doi: 10.1067/ mtc.2001.113596

13. Li C, Carli F, Lee L, et al. Impact of a trimodal prehabilitation program on functional recovery after colorectal cancer surgery: A pilot study. Surg Endosc. 2013; 27(4): 1072-1082. doi: 10.1007/ s00464-012-2560-5

14. Le Roy B, Selvy M, Slim K. The concept of prehabilitation: 
What the surgeon needs to know? J Visc Surg. 2016; 153(2): 109112. doi: $10.1016 /$ j.jviscsurg.2016.01.001

15. Le Roy B, Pereira B, Bouteloup C, et al. Effect of prehabilitation in gastro-oesophageal adenocarcinoma: Study protocol of a multicentric, randomised, control trial — the PREHAB study. BMJ Open. 2016; 6(12): e012876.
16. Baker A, Wooten LA, Malloy M. Nutritional considerations after gastrectomy and esophagectomy for malignancy. Curr Treat Options Oncol. 2011; 12(1): 85-95. doi: 10.1007/s11864-010-0134-0

17. Durrand JW, Batterham AM, Danjoux GR. Pre-habilitation (i): Aggregation of marginal gains. Anaesthesia. 2014; 69(5): 403-406. doi: $10.1111 /$ anae.12666 